Revista Latinoamericana de la Papa 22 (1): 12 - 37

ISSN: $1853-4961$

http://www.papaslatinas.org/revista.html

\title{
Evaluación de bacterias endófitas de papa nativa (Solanum tuberosum L.) y el desarrollo de un biofertilizante
}

\author{
N. Ortuñoo ${ }^{1 / *}$, M. Córdoba ${ }^{2}$, M. Claros ${ }^{2}$, J.A. Castillo ${ }^{3}$
}

Recibido: $24 / 04 / 2018$

Aceptado: $13 / 06 / 2018$

Accesible en línea: Junio 2018

\section{Resumen}

El desarrollo de biofertilizantes en base a microorganismos benéficos, es una alternativa ecológica al uso de fertilizantes sintéticos. Por lo cual es importante seleccionar cepas bacterianas, identificarlas y formularlas. Entre estos microorganismos se encuentran las bacterias endófitas promotoras de crecimiento vegetal, que tienen la capacidad de estimular el crecimiento de las plantas a través de diversos mecanismos. Se trabajó con la colección de la Fundación PROINPA, bacterianas endófitas, aisladas de cultivares de papa nativa, las cuales fueron seleccionadas para desarrollar un biofertilizante. Inicialmente se seleccionaron in vitro cepas en base a tres mecanismos funcionales: fijación de nitrógeno, solubilización de fosfato y producción de acido indol acético, para eso se seleccionó el $87 \%$ de las cepas fijan nitrógeno, el $70 \%$ solubilizan fosfato y el $34 \%$ producen acido indol acético. Después estas fueron evaluadas en vivero a inoculando plantas de dos cultivares de papa nativa (Polonia y Huaycha), donde las cepas: 33pa, IVpa, IIpa, IXpb y 2pf, presentaron los valores más altos en las variables de rendimiento, en las dos cultivares de papa evaluadas, donde la cepa 33pa destaca con los promedios más altos. Las mejores cepas seleccionadas fueron identificadas mediante pruebas bioquímicas y técnicas moleculares como Bacillus pumilus. Luego se optimizó el medio de cultivo para la producción masiva de la mejor cepa seleccionada, a través de diferentes extractos preparados con arroz, papa y otros, a los cuales se añadió diferentes fuentes de azúcares, donde la combinación de extracto de papa con con azúcar morena fue la mejor combinación. Y finalmente se realizó la formulación del biofertilizante, pelet (granulado) con la mejor cepa.

Palabras claves adicionales: Bioinsumos, Bacillus, Bacterias fijadoras de nitrógeno, PGPR.

\footnotetext{
* Autor para correspondencia. Correo electrónico: n.ortuno@umss.edu.bo

${ }^{1}$ Docente Facultad de Ciencias Agrícolas y Pecuarias, UMSS, Cochabamba, Bolivia.

${ }^{2}$ Investigadora independiente, Cochabamba, Bolivia.

${ }^{3}$ Docente - Investigador Universidad Yachay, Ibarra, Ecuador.
} 


\section{Evaluation of native potatoes in double bacteria and the development of a biofertilizer}

The development of biofertilizers based on beneficial microorganisms is an ecological alternative to the use of synthetic fertilizers. Among these microorganisms are endophytic plant growth promoting bacteria, which have the ability to stimulate the growth of plants through various mechanisms. We worked with the PROINPA Foundation collection, bacterial endophytes, isolated from native potato cultivars, which were selected to develop a biofertilizer. Initially in vitro strains were selected based on three functional mechanisms: nitrogen fixation, phosphate solubilization and production of indole acetic acid, for which $87 \%$ of the strains were selected to fix nitrogen, $70 \%$ solubilize phosphate and $34 \%$ produce acetic acid. Later these were evaluated in nursery by inoculating plants of two native potato cultivars (Poland and Huaycha), where the strains: 33pa, IVpa, IIpa, IXpb and 2pf, presented the highest values in the yield variables, in the two potato cultivars evaluated, where the 33pa strain stands out with the highest averages. The best selected strains were identified by biochemical tests and molecular techniques such as Bacillus pumilus. Then the culture medium was optimized for the mass production of the best selected strain, through different extracts prepared with rice, potatoes and others, to which different sources of sugars were added, where the combination of potato extract with brown sugar It was the best combination. And finally, the formulation of the biofertilizer, pellet (granulate) with the best strain was carried out.

Additional keywords: Bioinputs, Bacillus, Nitrogen fixing bacteria, PGPR.

\section{Introducción}

El uso intensivo de fertilizantes sintéticos ha causado alteraciones en el medio ambiente y eso se refleja, en la sociedad en su conjunto, en exigir productos agrícolas saludables. Por otro lado hay la necesidad de aumentar la productividad agrícola, pero con menos agroquímicos, debido a eso, en la actualidad, las investigaciones se han orientado hacia el desarrollo de innovaciones biotecnológica para la agricultura.

En los últimos años hay un interés creciente en los microorganismos benéficos del suelo, porque éstos pueden promover el crecimiento de las plantas y en algunos casos también evitar la infección del tejido vegetal por patógenos. Tales microorganismos pueden ser simbióticos o de vida libre (Benizri et al. 2001 y Bacilio-Jiménez et al. 2003). En este primer caso, se encuentran los endófitos, que son un grupo específico de microorganismos (bacterias, actinomicetos, hongos) que se encuentran asociadas a diversos tejidos vegetales, estos presentan una ocurrencia alta en los cultivos de importancia agrícola y alta relevancia en sus sistemas de producción (Surette \& Sturtz 2003).

Entre estos endófitos, están las bacterias promotoras de crecimiento vegetal (PGPB), estos presentan un metabolismo versátil con la capacidad de utilizar diversos sustratos liberados por la planta para su desarrollo. Adicionalmente poseen tiempos cortos de generación, alta movilidad, fijación biológica de nitrógeno, solubilización de fosfato y otros nutrientes (Wall 2001), también poseen la capacidad de colonizar las raíces y producción de metabolitos secundarios que pueden regular el crecimiento vegetal y regular las poblaciones microbianas rizósfericas (Kapulnik 2002).

Estos microorganismos son un grupo específico (bacterias, actinomicetos y 
hongos) que pueden encontrarse en diferentes tipos de tejidos vegetales incluyendo semillas, frutos, hojas, tubérculos, tallos, etc. Estos presentan una ocurrencia alta en los cultivos de importancia agrícola y alta relevancia en sus sistemas de producción (Surette \& Sturtz 2003). Estas muestran actividad como promotoras de crecimiento vegetal en diferentes cultivos de importancia económica como papa, tomate y arroz. Diversos aislamientos son capaces de inducir resistencia frente a estrés tanto biótico como abiótico en plantas inoculadas; también se ha demostrado que las comunidades de endófitos disminuyen el desarrollo de enfermedades y en algunas instancias la relación plantaendófito ha mostrado especificidad por el tipo de tejido de colonización (Surette \& Sturtz 2003).

Los microorganismos endófitos, al estar menos afectados por el estrés ambiental y más aclimatados con su simbionte (Sturz y Nowak 2000), podrían representar una mayor ventaja ecológica. Sin embargo, la presencia de bacterias endófitas y su papel dependen probablemente del cultivar y de su coevolución con la especie microbiana (Yanni et al. 2001).

Por otra parte, la capacidad para colonizar las raíces es una condición indispensable para que una bacteria sea considerada como una verdadera PGPB, siendo por tanto esa capacidad un primer paso y un rasgo crucial para la selección de los inóculos microbianos a ser usados como biofertilizantes, bioplaguicidas, fitoestimuladores o biorremediadores (Lugtenberg et al. 2001). Es también un primer indicio de que el microorganismo sea capaz de lograr el efecto benéfico esperado. Además de la capacidad de colonización, el éxito en la utilización de microorganismos promotores del crecimiento vegetal reside en el estudio de cepas compatibles y específicas a los diversos cultivos y a las condiciones ambientales prevalecientes (Peña \& Reyes 2007).

Por lo indicado, y en búsqueda de estrategias de manejo sustentable, es importante explorar la microflora, como las endófitas, aisladas de plantas de papa nativa, como promotoras de crecimiento vegetal, para eso hará la selección de cepas bacterianas endófitas, eficientes como promotores de crecimiento vegetal, provenientes de cultivares de papa nativa, se harán las caracterizaciones funcionales in-vitro como fijadoras de nitrógeno, solubilizadoras de fosfato y productoras de acido indol acético (AIA), luego se evaluará en vivero, se desarrollarán medios de cultivo para la multiplicación masiva determinar el mejor material inerte para la producción de un biofertilizante.

\section{Materiales y métodos}

Se utilizaron cepas de la colección de bacterias endófitas, del laboratorio de Microbiología Agrícola de la Fundación PROINPA, las que fueron aisladas de dos cultivares de papa nativa: Polonia ( $S$. tuberosum subsp. andigena) del departamento de La Paz y Malcacho $(S$. tuberosum subsp. andigena) del departamento de Chuquisaca y Potosí, con 26 y 21 cepas, respectivamente. Estos aislamientos bacterianos fueron aislamientos de muestras de raíz.

El estudio se realizó en cuatro fases: 1) in-vitro, donde se realizaron pruebas cualitativas en laboratorio, para caracterizar las cepas bacterianas de acuerdo a tres mecanismos funcionales de promotores de crecimiento vegetal: fijación biológica de nitrógeno (FBN), solubilización de fosfato (SP) y producción de ácido indol acético (AIA); 2) vivero, donde se inocularon las cepas 
bacterianas en plántulas de dos cultivares de papa nativa $y$ fueron evaluadas agronómicamente; 3) laboratorio, donde se hizo pruebas de optimización de medios de cultivo para la producción masiva de la mejor cepa seleccionada; y 4) planta de bioinsumos, donde se desarrolló la formulación del biofertilizante, con la mejor cepa seleccionada.

Para realizar la caracterización, primeramente se reactivó las cepas en estudio, mediante la siembra de estas cepas a un nuevo medio TSA (Triptic Soy Agar), y se incubó por 48 horas a $30^{\circ} \mathrm{C}$ para el crecimiento de las colonias.

\section{Caracterización funcional}

La determinación de bacterias endófitas fijadores de nitrógeno, se realizó en base al protocolo utilizado por Servin y Dion (2009). Donde se utilizó el medio Burk sólido, al cual se añadió azul bromofenol como indicador de $\mathrm{pH}$. Fue autoclavado durante $20 \mathrm{~min}$ a $121^{\circ} \mathrm{C}$ y 20 Psi de presión. El medio se vertió a placas Petri, y las cepas bacterianas fueron sembradas por extensión. En cada placa se probó cuatro cepas al mismo tiempo cada una sembrada en su respectivo cuadrante. Posteriormente las placas fueron incubadas por 48 horas a $30^{\circ} \mathrm{C}$.

Se empleó un control positivo y un control negativo, el control positivo consistió en una placa petri sembrada con una cepa de Bacillus pumilus fijadora de nitrógeno de la colección del laboratorio. Para su evaluación se observó la presencia de colonias y su acidificación.

Para determinar bacterias endófitas solubilizadoras de fósforo, se realizó en base al protocolo utilizado por Nautiyal (1999). Para eso se sembró cada cepa por extensión en placas petri, que contenían el medio de cultivo National Botanical
Research Institute's phosphate growth medium (NBRIP) con fosfato tricálcico. En cada placa se probó cuatro cepas al mismo tiempo cada una sembrada en su respectivo cuadrante. Posteriormente las placas fueron incubadas por 5-15 días a $30^{\circ} \mathrm{C}$. El tiempo de incubación puede variar dependiendo del género de bacteria con que se trabaje por esta razón se realizó un seguimiento diario de la prueba.

Se empleó un control positivo y un control negativo, el control positivo consistió en una placa petri sembrada con una cepa de Bacillus subtilis solubilizadora de fosfato, de la colección del laboratorio. En la evaluación se tomó como positivas las cepas que mostraron presencia de un halo transparente alrededor de la colonia.

Para la determinación de bacterias endófitas productoras de acido indol acético (AIA), se utilizó la metodología propuesta por Gordon (1950), adaptada a cada tipo de bacteria. Para esta prueba es muy importante considerar que el AIA es un metabolito secundario producido por algunas bacterias en el periodo estacionario de crecimiento, por esta razón el tiempo de incubación del caldo va a depender de la curva de crecimiento de la bacteria, se tendrá que dejar el tiempo suficiente para asegurarse que llegue a la fase estacionaria.

Se sembró cada cepa en tubos con medio líquido TSB (Triptic Soy Borth), suplementado con $5 \mathrm{mM}$ de L-Triptofano. Para esto se preparó primeramente TSB, después de su autoclavado, se añadió LTriptofano, éste por ser un aminoácido fue filtrado. Posteriormente se dosificó en tubos de $10 \mathrm{ml} \mathrm{a} 5 \mathrm{ml}$ de medio por tubo. Después de sembrar las cepas bacterianas, se incubaron en un agitador orbital con temperatura controlada, a $28^{\circ} \mathrm{C}, 100 \mathrm{rpm}$, 
por 7 días. Se empleó un control positivo y un control negativo, el control positivo consistió en un tubo sembrado con una cepa de Paenibacillus sp. productora de AIA, de la colección del laboratorio.

Transcurrida la semana de incubación, se procedió a la centrifugación de los caldos bacterianos en tubos Eppendorf (un Eppendorf por cepa); se colocó $1 \mathrm{ml}$ a cada tubo, y se centrifugó a razón de 5000 rpm, durante 5 minutos, en una centrifugadora (BIPEE 80-E). Para revelar el AIA en las muestras, se preparó el reactivo Salkowski, en una campana de extracción. Para el revelado, se colocó en pocillos una alícuota de $75 \mu \mathrm{L}$ del caldo bacteriano respectivo (solo se extrajo el sobrenadante, el precipitado fue desechado), se adicionó $225 \mu \mathrm{L}$ del reactivo de Salkowski (Fig. 13), y se incubó en oscuridad por 30 minutos. Se reportó como positivo si el medio vira de rosados claros a tonos rojizos.

\section{Evaluación en Vivero}

En vivero se realizó la inoculación de todas las cepas bacterianas en estudio, en dos cultivares de papa nativa: Polonia y Huaycha, esta última como planta indicadora (testigo) por ser el cultivar más comercial y difundido.

Se utilizó plántulas provenientes de multiplicación in vitro, por lo cual se procedió primeramente a su aclimatación. Estas fueron trasplantadas en sustrato estéril, en macetas de capacidad de 2 1/2 $\mathrm{kg}$. Posterior al ensayo, se realizo el análisis químico de los sustratos en el Laboratorio de Suelos y Aguas de la Facultad de Ciencias Agrícolas Pecuarias Forestales y Veterinaria, UMSS.

\section{Inóculo estandarizado}

La obtención del inoculo, se realizó mediante la multiplicación de las cepas en estudio en medio TSB. Para esto se dispensó en matraces Erlenmeyer de 25 $\mathrm{ml}$ con $15 \mathrm{ml}$ de medio por matraz, y se esterilizaron en autoclave. Posteriormente, en una cámara de flujo laminar, se sembraron las bacterias, y se incubó en un agitador orbital con temperatura controlada (LABNET) a $28^{\circ} \mathrm{C}, 100 \mathrm{rpm}$, durante una semana. Después de una semana de incubación, se estandarizaron las concentraciones bacterianas, a una concentración de $10^{8}$, para esto se realizaron diluciones de $10^{-1}$, $10^{-2}, 10^{-3}$ y $10^{-4}$ por cepa, y se contaron las bacterias en cámara Neubauer, a través de un microscopio. Cuando las cepas presentaron una menor concentración a $10^{8}$, se procedió a concentrar los caldos, a través del centrifugado de los mismos, y se preparó el inóculo en base al precipitado; en el caso contrario, cuando las cepas presentaron una mayor concentración a $10^{8}$, se preparó el inoculo diluyendo con agua destilada estéril; y cuando las bacterias no se multiplicaron en el medio, estas fueron descartadas.

\section{Inoculación de plantas con bacterias endófitas}

La inoculación de plantas con bacterias endófitas, se realizó en la etapa de plántula, a los 28 días del trasplante, después de la fase de la aclimatación. Con una micropipeta se inoculó el concentrado bacteriano de $250 \mu \mathrm{L}$ por planta, a nivel del cuello de la plántula, para la colonización de la raíz por los endófitos potenciales. Se cuidó de posibles contaminaciones o salpicaduras de una maceta a otra.

Variables de Respuesta. Las variables de crecimiento fueron medidas cada 15 días, estas fueron: la altura de la planta, y el número de tallos. Las variables de rendimiento se midieron en el momento 

de cosecha, estas fueron principalmente el número de tubérculos $\mathrm{y}$ peso de tubérculos, aunque también se cuantifico el peso fresco y seco de la parte aérea, y el peso fresco y seco de la raíz.

Los tratamientos fueron estructurados, en factorial completo, con dos cultivares de papa, 47 cepas bacterianas, mas una cepa conocida para los tratamientos positivos (Bacillus subtilis comercial), y los testigos (cultivares de papa sin cepas). Un total de 98 tratamientos, con tres repeticiones. Sin embargo, el testigo presentó más repeticiones por ajustes a los bloques del diseño. Presentando un total de 300 unidades experimentales.

Se utilizó un diseño de bloques Incompletos en látice triple (Cochran y Cox 1965). El análisis estadístico, se realizó mediante el programa estadístico SAS versión 9.2. Para el análisis de las variables, se realizó el análisis de clúster utilizando el método Ward, donde la distancia entre dos clúster se calcula como la suma de cuadrados entre grupos en el MANOVA sumando para todas las variables. En cada paso se minimiza la suma de cuadrados dentro de los clúster sobre todas la particiones posibles obtenidas fusionando dos clúster del paso anterior. Las sumas de cuadrados son más fáciles de entender cuando se expresan como porcentaje de la suma de cuadrados total. Para medir la distancia entre las accesiones se utilizó la distancia Euclidiana. Así, dados dos objetos $\mathbf{I}_{\mathbf{1}}$ y $\mathbf{I}_{\mathbf{2}}$ medidos según dos variables x1 y x2, la distancia euclídeana entre ambos.

\section{Pruebas Bioquímicas}

Para la identificación de las cepas bacterianas seleccionadas, se realizó la caracterización mediante pruebas bioquímicas de manera complementaria (Pérez 2004). Se realizaron las pruebas de: identificación de Bacillus spp., amilasa, oxidasa, catalasa, $\mathrm{KOH}$ y tinción de GRAM.

\section{Prueba de identificación de Bacillus sp.}

Primeramente, se colocó $500 \mu \mathrm{l}$ de agua destilada estéril, en tubos Eppendorf, los cuales fueron inoculados con la muestra bacteriana, y fueron sometidos a un choque térmico, colocando los tubos en baño maría, un tiempo de $12 \mathrm{~min}$. a $80^{\circ} \mathrm{C}$. Posteriormente se realizó la siembra de estos tubos, en placas con medio TSA, y fueron colocadas en incubación por 48 horas. Se reportaron como positivas las cepas que crecieron sobre el medio.

\section{Prueba de Amilasa}

Se preparó el medio agar-almidón, en el cual se realizó la siembra de las cepas en cuadrantes. Posteriormente se colocó en la incubadora a $30^{\circ} \mathrm{C}$ por un día. Transcurrido este tiempo se realizó el revelado con Yodo. Se reportó como positivo las cepas que presentaron halos.

\section{Prueba de Oxidasa}

En un portaobjetos desinfectado con alcohol, se colocó los discos de oxidasa, sobre los cuales se puso la muestra bacteriana, con mondadientes esterilizados, y por último se colocó una gota de agua destilada estéril sobre esta muestra. Transcurridos 5 min se observó el cambio de coloración. Se reportó como positivo, si presentaba un cambio de coloración la muestra bacteriana.

\section{Prueba de Catalasa}

Primeramente, en un portaobjetos desinfectado, se colocó con un monda diente esterilizado, la muestra bacteriana, y posteriormente se colocó una gota de agua oxigenada al 3\% (H2O2) sobre la muestra. Se reportó como positiva la presencia de burbujeo.

\section{Prueba de KOH}



Sobre un portaobjetos desinfectado se colocó una muestra bacteriana, con una micropipeta se dejó caer una gota de $\mathrm{KOH}$ al $10 \%$ sobre la muestra. Posteriormente se mezcló con un mordadiente estéril. Se reportó como positivo, cuando se levantó un hilo viscoso con el monda diente.

\section{Tinción de Gram}

Para la tinción de Gram se realizó la extensión, fijación, coloración y el secado, siguiendo el protocolo estándar para la tinción de Gram. Posteriormente, se procedió a la observación en el microscopio.

\section{Identificación Molecular}

La identificación molecular, se mandaron las cepas al laboratorio de Biología Molecular de la Fundación PROINPA. Primeramente se realizó una amplificación por PCR del gen que codifica al ARN ribosomal, 16S. Posteriormente se secuenció los fragmentos, con la secuencia de ADN se buscó secuencias similares por alineamiento en las bases de datos.

\section{Evaluación de medios de cultivo para la producción masiva}

Para la multiplicación masiva de la mejor cepa bacteriana seleccionada, se realizaron pruebas en diferentes medios de cultivo. Se probaron medios de cultivo o caldos nutrientes de: papa, camote, cebada, trigo, soya y haba. Los caldos de papa y camote se obtuvieron a través de la cocción de los mismos por 15 min, en una relación de $200 \mathrm{~g}$ en $600 \mathrm{ml}$ de agua destilada. Los caldos de cebada, trigo, haba y soya, se obtuvieron colocando la harina de los mismos en agua en su punto de ebullición, en una relación de $0.75 \mathrm{~g}$ en $150 \mathrm{ml}$ de agua destilada.

Se utilizaron matraces Erlenmeyer de 500 ml, en cada matraz se colocó $150 \mathrm{ml}$ de caldo, y se esterilizaron en autoclave por 15 min a $121^{\circ} \mathrm{C}$ y 20 Psi de presión. Posteriormente se realizó la siembra en los caldos respectivos, con una misma concentración de inóculo, de $10^{8}$, el cual se registró como la concentración inicial. Los caldos fueron trasferidos a un agitador orbital con temperatura controlada, para su incubación y multiplicación masiva, por 48 horas, a $30^{\circ} \mathrm{C}$ y $100 \mathrm{rpm}$.

Cada caldo presentó tres repeticiones, un testigo, que consiste en el caldo sin inoculación, y un testigo positivo, que consiste en caldo de soya inoculado. La evaluación se realizó transcurridas las 48 horas de incubación, y se tomaron datos de: a) Concentración bacteriana, la cuantificación se realizó mediante el conteo en cámara Neubauer, y b) Evaluación del $\mathbf{p H}$, medido a través de un pHmetro, como también se tomo el pH inicial, es decir, antes de la inoculación.

\section{Evaluación de medios de cultivo para la multiplicación masiva con diferentes fuentes de energía}

Para optimizar el mejor medio de cultivo encontrado en la anterior prueba, se realizó pruebas con cuatro diferentes azúcares: azúcar blanca, azúcar morena, glucosa y chancaca.

La metodología empleada para la preparación, inoculación e incubación de los medios de cultivo, fue la misma que se empleó en la prueba anterior. Exceptuando la adición de los azúcares en los medios de cultivo, que fue realizada en una relación de $20 \mathrm{~g}$ del azúcar en 600 $\mathrm{ml}$ del medio de cultivo preparado, el cual 
se realizó antes del autoclavado. La evaluación, se realizó transcurrida las 48 horas de incubación, y se tomaron datos de: a) Concentración bacteriana, la cuantificación se realizó mediante el conteo en cámara Neubauer, b) Evaluación del $\mathbf{p H}$, medido a través de un pHmetro, como también se tomo el $\mathrm{pH}$ inicial, es decir, antes de la inoculación, y c) Grados Brix, medido a través de un Refractómetro.

\section{Evaluación de medios inertes para la formulación del biofertilizante}

\section{Formulación en polvo}

Para la formulación en polvo, se realizó la mezcla del caldo bacteriano con dos diferentes medios inertes: caolín y calcita. Primeramente se realizó cálculos previos a la formulación, para definir la proporción adecuada de insumos a utilizarse en la mezcla, por lo que se usó la relación de $300 \mathrm{ml}$ de caldo bacteriano con $500 \mathrm{~g}$ de medio inerte, tanto para caolín como para calcita. El mezclado se realizó en una mezcladora manual, pequeña. Posteriormente se colocó en bandejas, para el secado en un horno por circulación de aire, a temperatura ambiente, y se realizó el molido en un mortero.

\section{Formulación en pellet}

Para la formulación en pellet, también se realizaron cálculos previos a la formulación, para definir la proporción adecuada de insumos a utilizarse en la mezcla. Por lo que se definió utilizar: una relación de $300 \mathrm{ml}$ de caldo bacteriano con $2844,4 \mathrm{~g}$ de medio inerte. El medio inerte esta compuesto por calcita, caolín granulado y melaza

Primeramente, en una bolsa plástica resistente, se realizó una mezcla del caldo bacteriano con calcita, seguidamente se le añadió melaza y se mezcló nuevamente, posteriormente se adicionó caolín granulado, y se realizó una última mezcla. La mezcla fue colocada en bandejas, para el secado en un horno por circulación de aire.

Posteriormente se realizó la evaluación de estas formulaciones, y se evaluó los siguientes parámetros: viabilidad (bacterias totales), $\mathrm{pH}$, tiempo de secado, consistencia en seco y solubilidad en agua.

\section{Evaluación de la viabilidad}

La evaluación de la viabilidad, se realizó a través, de la siembra por vertido en medio TSA, de las diluciones de ambos formulados, a $10^{-3}$ y $10^{-4}$, y se colocó en la incubadora a $30{ }^{\circ} \mathrm{C}$ por 48 horas. Transcurrido ese tiempo, se realizó el conteo de unidades formadoras de colonias. 


\section{Resultados y discusión}

\section{Pruebas in-vitro}

Las pruebas cualitativas realizadas a las cepas en estudio, considerando tres mecanismos funcionales, de fijación biológica de nitrógeno, solubilización de fosfato y producción de ácido indol acético, mostraron los siguientes resultados:

En la prueba de fijación de nitrógeno, se observó este mecanismo a través del desarrollo de la colonia en el medio Burk, por que este medio tiene la característica de contener poca fuente de nitrógeno, de manera que las bacterias que se desarrollan bajo este medio tienen la capacidad de reducir el nitrógeno gaseoso $\left(\mathrm{N}_{2}\right)$ para producir $\mathrm{NH}_{4}{ }^{+}$(amonio), que después sirve para la biosíntesis de aminoácidos (Servin \& Dion 2009).

Como también, por la adición del indicador de $\mathrm{pH}$ (azul bromofenol) al medio Burk, se observó la acidificación de este medio por parte de la cepa bacteriana. La acidificación del medio se evidenció a través del cambio de coloración, de azul a amarillo, indicando un pH ácido (Nautiyal 1998).

En la prueba de solubilización de fosfato, se observó un halo transparente alrededor de la colonia de las cepas bacterianas que solubilizan fosfato. Según Metha \& Nautiyal (2001), estos halos o zonas claras alrededor de las colonias, indican un viraje en el $\mathrm{pH}$ del medio por la secreción de ácidos orgánicos, tales como el láctico, oxálico y cítrico, por parte de estos microorganismos. Estos ácidos orgánicos solubilizan formas orgánicas e inorgánicas de fósforo no disponible, para la asimilación de la planta.

Por otra parte, en la prueba de producción de ácido indol acético, se observó el cambio de coloración del medio, de tonos rosados a rojizos de las cepas que producen ácido indol acético. Según Hans et al. (1997), esta auxina actúa a nivel génico regulando la expresión de múltiples genes. El AIA se une a un receptor de naturaleza proteica, formando un complejo receptor-hormona de carácter reversible, específico, con alta afinidad y saturable. Este complejo activa un promotor que controla la expresión de los genes que codifican la síntesis de las enzimas catalizadoras de los compuestos de la pared, estimulando de esta manera el crecimiento de la planta.

Entre las cepas provenientes del cultivar Malcacho (Tabla 1), se encontraron que el $80 \%$ de las cepas fijan nitrógeno, el $71 \%$ solubilizan fosfato y el $52 \%$ de las cepas producen AIA. Las cepas 5pa, 6pc, 6pf, 6pg, 7pa, 7pd y 7pe, actúan sobre los tres mecanismos, en cambio, la cepa $5 \mathrm{pb}$ no realiza ninguna de las actividades funcionales analizadas. Las cepas $5 \mathrm{pa}$ y 7 pe fueron las únicas que acidificaron el medio Burk, en la prueba de fijación de nitrógeno. 
Tabla 1. Caracterización de cepas aisladas de papa cv. Malcacho.

\begin{tabular}{|c|c|c|c|c|c|}
\hline \multirow[b]{2}{*}{$\mathbf{N}^{\mathbf{o}}$} & \multirow[b]{2}{*}{ Cepas } & \multicolumn{2}{|c|}{ Fijación de Nitrógeno } & \multirow{2}{*}{$\begin{array}{c}\text { Solubilización de } \\
\text { Fosfato } \\
\end{array}$} & \multirow{2}{*}{$\begin{array}{c}\text { Producción de } \\
\text { Acido Indol Acético }\end{array}$} \\
\hline & & Presencia de colonia & Acidificación & & \\
\hline 1 & $2 \mathrm{pa}$ & + & - & + & - \\
\hline 2 & $2 \mathrm{pb}$ & + & - & + & - \\
\hline 3 & $2 \mathrm{pc}$ & - & - & - & + \\
\hline 4 & $2 \mathrm{pd}$ & - & - & - & + \\
\hline 5 & $5 \mathrm{pa}$ & + & + & + & + \\
\hline 6 & $5 \mathrm{pb}$ & - & - & - & - \\
\hline 7 & $5 \mathrm{pc}$ & + & - & + & - \\
\hline 8 & $6 \mathrm{pa}$ & + & - & + & - \\
\hline 9 & $6 \mathrm{pb}$ & + & - & - & + \\
\hline 10 & $6 \mathrm{pc}$ & + & - & + & + \\
\hline 11 & $6 \mathrm{pd}$ & + & - & - & + \\
\hline 12 & $6 \mathrm{pe}$ & + & - & - & - \\
\hline 13 & $6 \mathrm{pf}$ & + & - & + & + \\
\hline 14 & $6 \mathrm{pg}$ & + & - & + & + \\
\hline 15 & $6 \mathrm{ph}$ & - & - & + & - \\
\hline 16 & $6 \mathrm{pi}$ & + & - & + & - \\
\hline 17 & $7 \mathrm{pa}$ & + & - & + & + \\
\hline 18 & $7 \mathrm{pb}$ & + & - & + & - \\
\hline 19 & $7 \mathrm{pc}$ & + & - & + & - \\
\hline 20 & $7 \mathrm{pd}$ & + & - & + & + \\
\hline 21 & $7 \mathrm{pe}$ & + & + & + & + \\
\hline
\end{tabular}

En cuanto a las cepas provenientes del cultivar Polonia (Tabla 2), el $92 \%$ de las cepas fijan nitrógeno, el $69 \%$ solubilizan fosfato y el $19 \%$ produce acido indol acético. Las cepas 2pf, 3pb, 3pc y IIpb, realizan los tres mecanismos, en cambio la cepa $33 \mathrm{pb}$, no realiza ninguna de estas funciones analizadas, y las cepas 3 pa y IIpb, acidificaron el medio Burk, en la prueba de fijación de nitrógeno. 
Tabla 2. Caracterización de cepas aisladas de papa cv. Polonia.

\begin{tabular}{|c|c|c|c|c|c|}
\hline \multirow[b]{2}{*}{$\mathbf{N}^{\circ}$} & \multirow[b]{2}{*}{ Cepas } & \multicolumn{2}{|c|}{ Fijación de Nitrógeno } & \multirow{2}{*}{$\begin{array}{c}\text { Solubilización de } \\
\text { Fosfato } \\
\end{array}$} & \multirow{2}{*}{$\begin{array}{c}\text { Producción de } \\
\text { Acido Indol Acético }\end{array}$} \\
\hline & & Presencia de colonia & Acidificación & & \\
\hline 1 & $1 \mathrm{pa}$ & + & - & + & - \\
\hline 2 & $1 \mathrm{pb}$ & + & - & + & - \\
\hline 3 & $1 \mathrm{pc}$ & + & - & + & - \\
\hline 4 & $2 \mathrm{pe}$ & + & - & - & - \\
\hline 5 & $2 \mathrm{pf}$ & + & - & + & + \\
\hline 6 & $3 \mathrm{pa}$ & + & + & + & - \\
\hline 7 & $3 \mathrm{pb}$ & + & - & + & + \\
\hline 8 & $3 \mathrm{pc}$ & + & - & + & + \\
\hline 9 & $31 \mathrm{pa}$ & + & - & + & - \\
\hline 10 & $31 \mathrm{pb}$ & + & - & - & - \\
\hline 11 & $31 \mathrm{pc}$ & + & - & + & - \\
\hline 12 & $31 \mathrm{pd}$ & + & - & - & - \\
\hline 13 & $32 \mathrm{pa}$ & + & - & + & - \\
\hline 14 & $32 \mathrm{pb}$ & + & - & + & - \\
\hline 15 & $32 \mathrm{pc}$ & + & - & + & - \\
\hline 16 & $32 \mathrm{pd}$ & + & - & - & - \\
\hline 17 & 32pe & + & - & + & - \\
\hline 18 & $33 \mathrm{pa}$ & + & - & + & - \\
\hline 19 & $33 \mathrm{pb}$ & - & - & - & - \\
\hline 20 & Ilpa & - & - & + & - \\
\hline 21 & Ilpb & + & + & + & + \\
\hline 22 & Ilpc & + & - & + & - \\
\hline 23 & IIIpa & + & - & - & - \\
\hline 24 & IVpa & + & - & + & - \\
\hline 25 & IXpa & + & - & - & - \\
\hline 26 & $\mathrm{IXpb}$ & + & - & - & + \\
\hline
\end{tabular}

\section{Pruebas en Vivero}

Para la evaluación de todas las cepas bacterianas como promotores de crecimiento vegetal, se realizó el seguimiento al ensayo implementado en vivero, y la evaluación correspondiente del ciclo vegetativo de las dos cultivares de papa (Polonia y Huaycha).

Inicialmente, en base a todas los cultivares evaluados, se hizo un análisis de Cluster, para agrupar las cepas bacterianas y así identificar las más eficientes. Una vez definidos estos grupos, se realizó el análisis de varianza multivariado, considerando las dos variedades de papa, donde se encontraron diferencias altamente significativas entre los cultivares $(\mathrm{p}=0,01)$, y diferencias significativas en los tratamientos, y la interacción cultivar-tratamiento $(\mathrm{p}=0,05)$.

Se obtuvo una gráfica general de agrupamiento de cepas bacterianas, sin separar los cultivares de papa, realizando un corte a una distancia de 0,05 de la 
gráfica de Cluster, se observó cinco grupos de cepas bacterianas. El mejor grupo fue seleccionado, comparando las medias de los componentes de rendimiento (número de tubérculos y el peso de los tubérculos) (Tabla 3). El grupo 5 fue seleccionado como el mejor, porque presentó los valores más altos en las medias de la variable de rendimiento; donde están ubicadas 19 cepas.

Tabla 3. Medias generales para las variables de crecimiento y rendimiento, de los cultivares Polonia y

\begin{tabular}{|c|c|c|c|c|c|c|c|c|}
\hline Grupo & $\begin{array}{c}\text { Peso Fresco } \\
\text { Hoja }\end{array}$ & $\begin{array}{c}\text { Peso } \\
\text { Seco Hoja }\end{array}$ & $\begin{array}{l}\text { Altura } \\
\text { Planta }\end{array}$ & $\begin{array}{l}\mathrm{N}^{\circ} \mathrm{de} \\
\text { Tallos }\end{array}$ & $\begin{array}{c}\text { Peso Fresco } \\
\text { Raíz } \\
\end{array}$ & $\begin{array}{c}\text { Peso Seco } \\
\text { Raíz }\end{array}$ & $\begin{array}{c}\mathrm{N}^{\mathrm{o}} \\
\text { Tubérculo }\end{array}$ & $\begin{array}{c}\text { Peso } \\
\text { Tubérculo }\end{array}$ \\
\hline 1 & 58,22 & 5,79 & 114,03 & 6,10 & 26,35 & 5,11 & 8,12 & 32,69 \\
\hline 2 & 67,50 & 6,36 & 104,93 & 6,93 & 30,71 & 5,47 & 9,64 & 34,29 \\
\hline 3 & 72,29 & 6,98 & 118,36 & 6,50 & 31,88 & 5,27 & 7,67 & 30,42 \\
\hline 4 & 43,13 & 4,31 & 98,50 & 5,50 & 26,88 & 4,49 & 8,13 & 23,13 \\
\hline 5 & 54,14 & 5,35 & 99,67 & 6,33 & 30,79 & 5,72 & 9,86 & 38,75 \\
\hline
\end{tabular}

Por otra parte, también se hizo otros agrupamientos de las cepas bacterianas, para cada cultivar de papa. Realizando un corte a una distancia de 0,05 de sus graficas de Cluster, se observaron 6 grupos para el cultivar Polonia y 6 grupos para el cultivar Huaycha.

En base a las variables de rendimiento, en la var. Polonia, se seleccionó el grupo 3
(Tabla 4), porque presentó los mayores valores en número y peso de tubérculo, respecto al resto de los otros grupos de cepas. En el cultivar Huaycha, el mejor grupo fue el 3 (Tabla 5). En ambos casos, se consideraron también los segundos mejores grupos para la selección de las mejores

cepas.

Tabla 4. Medias para las variables de crecimiento y rendimiento, del cultivar Polonia.

\begin{tabular}{|c|c|c|c|c|c|c|c|c|}
\hline Grupo & $\begin{array}{c}\text { Peso Fresco } \\
\text { Hoja }\end{array}$ & $\begin{array}{c}\text { Peso Seco } \\
\text { Hoja }\end{array}$ & $\begin{array}{l}\text { Altura } \\
\text { Planta }\end{array}$ & $\mathrm{N}^{\circ}$ de Tallo & $\begin{array}{c}\text { Peso Fresco } \\
\text { Raíz }\end{array}$ & $\begin{array}{c}\text { Peso Seco } \\
\text { Raíz }\end{array}$ & $\begin{array}{c}\mathrm{N}^{\mathbf{o}} \\
\text { Tubérculo }\end{array}$ & $\begin{array}{c}\text { Peso } \\
\text { Tubérculo }\end{array}$ \\
\hline 1 & 65,92 & 6,88 & 102,91 & 8,50 & 41,14 & 7,28 & 8,94 & 26,15 \\
\hline 2 & 49,96 & 5,34 & 103,08 & 7,45 & 41,14 & 7,27 & 8,70 & 26,30 \\
\hline 3 & 56,30 & 5,93 & 86,89 & 8,70 & 46,50 & 7,70 & 9,31 & 32,70 \\
\hline 4 & 60,73 & 6,45 & 148,76 & 5,83 & 21,67 & 4,40 & 5,83 & 16,45 \\
\hline 5 & 59,42 & 5,88 & 127,24 & 7,36 & 36,07 & 6,06 & 7,99 & 21,43 \\
\hline 6 & 57,22 & 5,46 & 114,30 & 6,17 & 26,17 & 5,06 & 6,68 & 19,38 \\
\hline
\end{tabular}

Tabla 5. Medias para las variables de crecimiento y rendimiento, de la variedad Huaycha.

\begin{tabular}{crrrrrrrr}
\hline & \multicolumn{1}{c}{$\begin{array}{c}\text { Peso } \\
\text { Fresco } \\
\text { Grupo }\end{array}$} & \multicolumn{1}{c}{$\begin{array}{c}\text { Peso Seco } \\
\text { Hoja }\end{array}$} & \multicolumn{1}{c}{$\begin{array}{c}\text { Altura } \\
\text { Planta }\end{array}$} & $\mathrm{N}^{\mathbf{o}}$ de Tallo & $\begin{array}{c}\text { Peso } \\
\text { Fresco Raíz }\end{array}$ & $\begin{array}{c}\text { Peso Seco } \\
\text { Raíz }\end{array}$ & $\begin{array}{c}\mathrm{N}^{\mathbf{0}} \\
\text { Tubérculo }\end{array}$ & $\begin{array}{c}\text { Peso } \\
\text { Tubérculo }\end{array}$ \\
\hline 1 & 70,4 & 6,47 & 107,46 & 5,21 & 25,07 & 4,36 & 9,01 & 42,58 \\
\hline $2 \mathrm{z}$ & 72,9 & 6,66 & 129,07 & 6,5 & 19,5 & 3,97 & 7,62 & 32,22 \\
\hline 3 & 53,38 & 4,84 & 96 & 5,25 & 25,31 & 4,52 & $\mathbf{1 2 , 8 5}$ & $\mathbf{6 0 , 1 5}$ \\
4 & 56,3 & 4,81 & 70,79 & 4 & 21,88 & 4,32 & 11,89 & 53,77 \\
5 & 30,19 & 3,31 & 68,79 & 4,5 & 25 & 3,11 & 8,32 & 13,01 \\
6 & 49,65 & 5,01 & 106,36 & 5 & 17,86 & 4,39 & 9,48 & 44,55 \\
\hline
\end{tabular}



Las mejores cepas bacterianas se seleccionaron, comparando las cepas bacterianas en los dos cultivares de papa, y se obtuvieron las cepas: 33pa, IVpa,
IIpa, IXpb y 2pf, como las mejores inductoras de crecimiento (Tabla 6).

Tabla 6. Características de las mejores cepas seleccionadas.

\begin{tabular}{cccccccc}
\hline & Fijación de & Solubilización & Producción de & & \multicolumn{2}{c}{ Procedencia } \\
\hline Cepa & Nitrógeno & de Fosfato & Acido Indol Acético & Departamento & Localidad & Variedad \\
\cline { 5 - 8 } $33 \mathrm{pa}$ & + & + & - & La Paz & Cariquina Grande & Polonia \\
\hline $\mathrm{IVpa}$ & + & + & - & La Paz & Cariquina Grande & Polonia \\
\hline $\mathrm{IIpa}$ & - & + & - & La Paz & Cariquina Grande & Polonia \\
\hline $\mathrm{IXpb}$ & + & - & + & La Paz & Cariquina Grande & Polonia \\
\hline $2 \mathrm{pf}$ & + & + & + & La Paz & Cariquina Grande & Polonia \\
\hline
\end{tabular}

Estas cinco cepas seleccionadas, se comportan de manera diferenciada en cuanto al mecanismo funcional de promotor de crecimiento. Sin embargo,

Las cepas 33pa y IVpa, fijan nitrógeno y solubilizan fosfato, pero no producen AIA, en cambio la cepa IIpa solo solubiliza fosfato, la cepa IXpb, fija nitrógeno y produce AIA, y la cepa $2 \mathrm{pf}$ realiza los tres mecanismos funcionales. Esto muestra que las bacterias endófitas de la papa nativa pueden realizar diferentes funciones $\mathrm{o}$ una sola, posiblemente este tipo de microorganismos generan efectos complementarios y aditivos respecto a un factor determinado como las cepas 33pa y IVpa con la cepa IIpa respecto a la solubilización del fosfato.

Posteriormente se realizó un análisis de correlación general, se encontró una correlación significativa $(\mathrm{p}=0,01)$ y positiva entre el peso fresco hoja, con peso seco hoja, como también entre el número de tubérculo y peso tubérculo. Para el cultivar Polonia, se detectó una correlación significativa y positiva $(p=0,01)$ entre peso de tubérculo y todas presentan la misma procedencia, es decir, el mismo lugar y aisladas del mismo cultivar de papa, Polonia del Altiplano de La Paz.

número de tubérculo, como también entre peso fresco hoja y peso seco hoja, entre número de tallos y peso fresco raíz, entre peso fresco raíz y peso seco raíz, y se encontró una correlación significativa y negativa entre la altura de planta y peso fresco raíz. Asimismo, en Huaycha, se encontró una correlación significativa y positiva entre peso tubérculo y número de tubérculo, entre altura planta y peso seco hoja, y entre peso fresco hoja y peso seco hoja. Estas correlaciones demuestran que los efectos de tratamientos pueden incidir de diferente forma en los cultivares de papa utilizados.

\section{Curvas de Crecimiento}

En base a variables evaluadas periódicamente la altura de planta, a lo largo del desarrollo fenológico de las plantas en el ensayo, se graficó las curvas para las cinco mejores cepas mas el testigo, para su respectiva comparación. Se realizaron las regresiones lineales simples. 



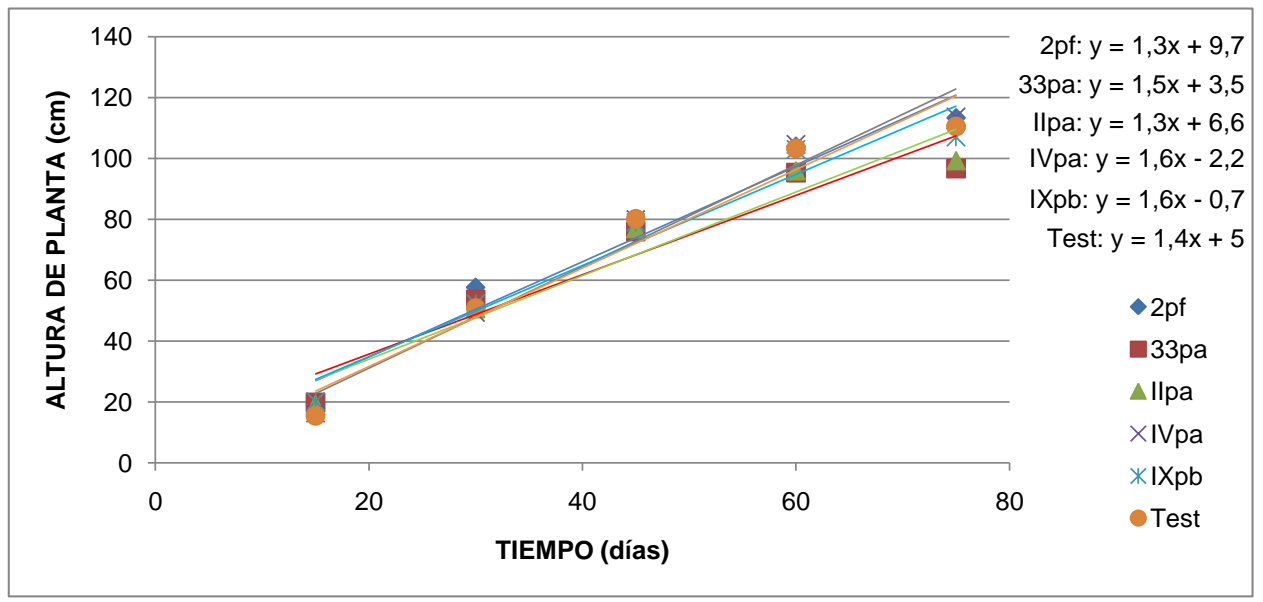

Figura 1. Variación de la altura de planta en el cultivar Polonia a través del tiempo.

La variable de altura planta, mostró una pendiente ascendente, que indica el crecimiento progresivo de la planta. En cv. Polonia (Figura 1), las plantas inoculadas con la cepa IVpa presentaron mayor altura. En cambio el cv. Huaycha (Figura 2), fueron con la cepa IIpa las de mayor altura de planta. Las plantas con menor altura de planta en el cv. Polonia y Huaycha fueron con la cepa 33pa. En cambio en las plantas testigo en ambas variedades presentaron una altura promedio de planta.

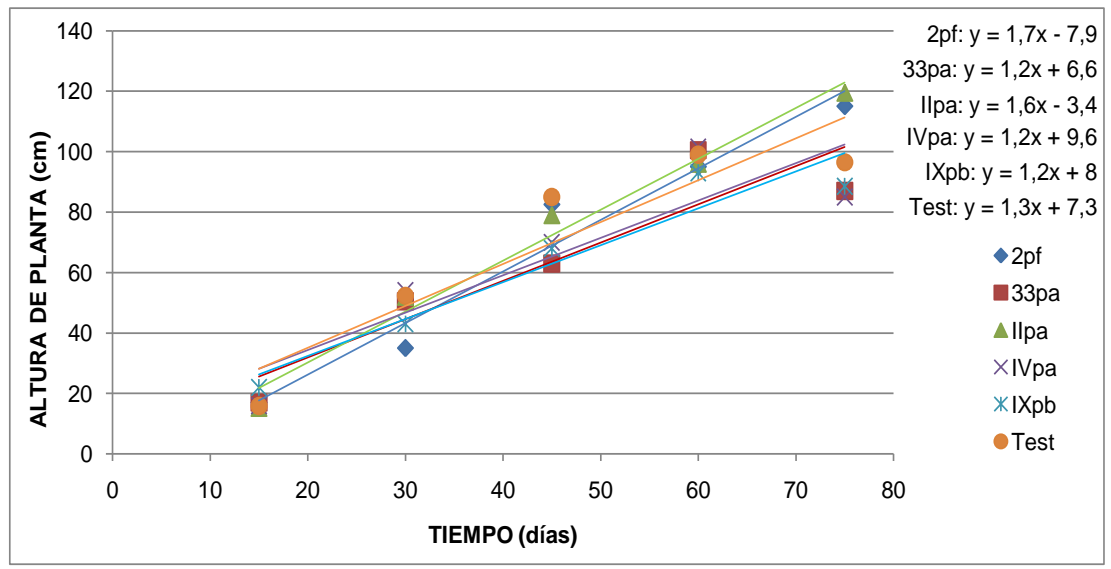

Figura 2. Variación de la altura de planta en el cultivar Huaycha a través del tiempo.

\section{Rendimiento}

Para estimar los rendimientos alcanzados en vivero, se realizó la conversión de $\mathrm{Kg} /$ planta a t/ha, y luego se realizó el análisis de varianza, para todas las cepas en estudio, donde se encontró diferencias altamente significativas $(\mathrm{p}=0,01)$ entre los cultivares de papa, y diferencias significativas $(\mathrm{p}=0,05)$ entre las cepas y en la interacción del cultivar con la cepa. 
Entre los cultivares de papa evaluadas, el cv. Huaycha presentó mayores rendimientos, a diferencia del cv. Polonia, que presentó menores rendimientos
(Figura 3), lo cual se puede explicar a las diferencias debidas al genotipo de cada cultivar.

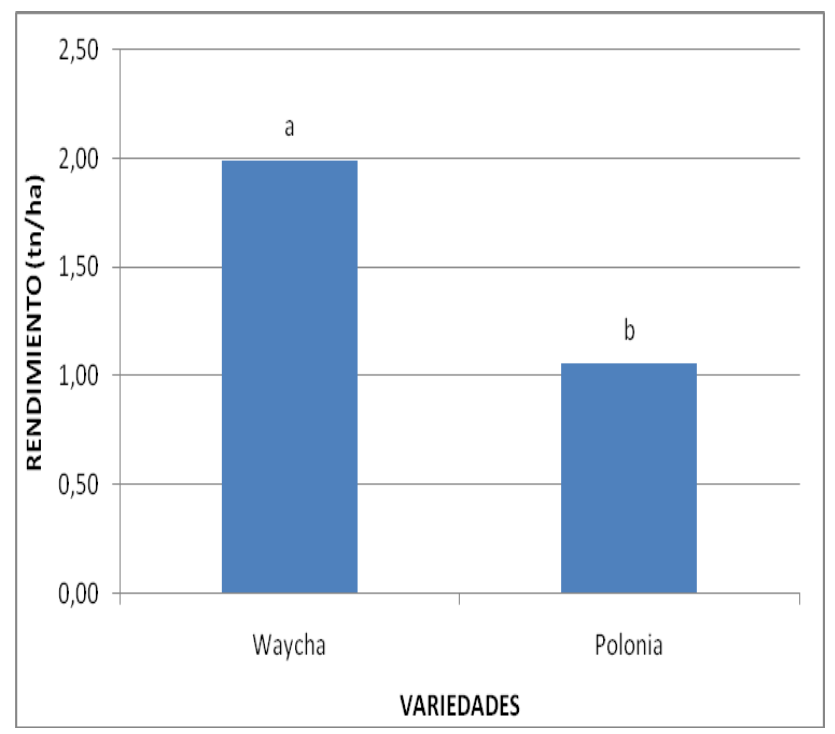

Figura 3. Efecto de las cepas sobre el rendimiento de los cultivares Huaycha y Polonia.

En el rendimiento para el cultivar Polonia (Figura 4), 8 cepas presentaron mayores rendimientos que el resto de las cepas, estas fueron: IIpb, IIIpa, 7pc, 6pf, 33pa, 2pf, 2pd y 1pa. Siendo las más destacables las cepas IIIpa, 33pa, 2pf y $2 \mathrm{pd}$, por presentar mayor promedio.

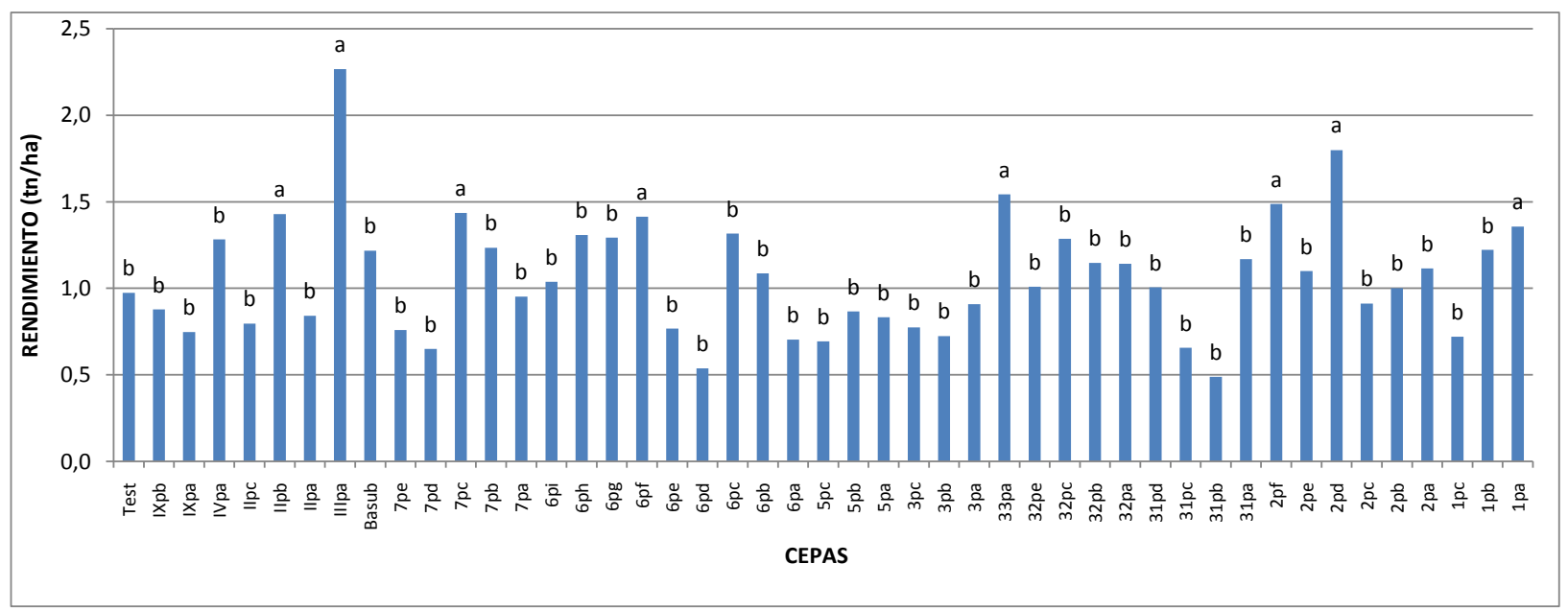

Figura 4. Efecto de las cepas sobre el rendimiento en el cv. Polonia.

El cultivar Huaycha (Figura 5), presentó mejores rendimientos con 20 cepas: $2 \mathrm{pc}$, 2pf, 31pb, 31pc, 33pa, 3pa, 3pb, 5pa, 6pa, 6pb, 6pe, 6pf, 7pb, 7pd, 7pe, IIpa, IIpc, IVpa, IXpa y IXpb. Siendo las mas destacables las cepas 2 pf y 6 pe por tener 


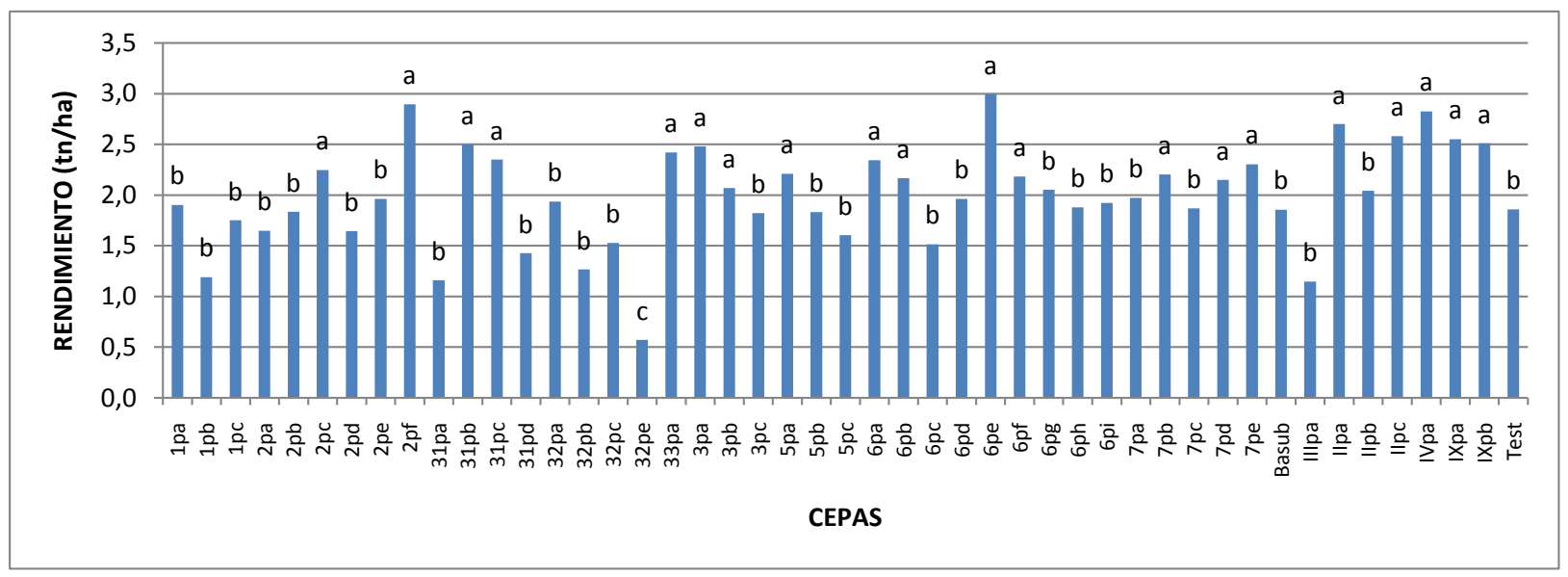

Figura 5. Efecto de las cepas sobre el rendimiento en el cv. Huaycha.

Sin embargo, por criterios de selección, no todas estas cepas con rendimientos destacables fueron seleccionadas, porque solo se destacaron en uno de los cultivares.

\section{Identificación de cepas seleccionadas}

Las once mejores cepas seleccionadas, fueron caracterizadas mediante las diferentes pruebas bioquímicas, $\mathrm{y}$ posteriormente fueron identificadas molecularmente.

\section{Pruebas Bioquímicas}

Con las cepas seleccionadas después de realizar las pruebas bioquímicas, se encontraron los comportamientos diferenciados entre ellas $(\mathrm{p}=0,01)$, donde el signo (+) indica una reacción positiva de la cepa. Determinándose que la mayoría de las cepas corresponden al género Bacillus, Gram positivos y catalasa positiva (Tabla 7). 
Tabla 7. Pruebas Bioquímicas.

\begin{tabular}{ccccccc}
\hline Cepa & Bacillus & Amilasa & Oxidasa & Catalasa & KOH & T. GRAM \\
\hline $33 \mathrm{pa}$ & + & + & + & + & - & + \\
\hline $\mathrm{IVpa}$ & - & - & - & + & + & + \\
\hline $\mathrm{IIpa}$ & - & - & - & + & - & - \\
\hline $\mathrm{IXpb}$ & - & - & - & + & - & + \\
\hline $2 \mathrm{pf}$ & + & - & + & + & + & + \\
\hline $31 \mathrm{pc}$ & + & + & + & + & - & + \\
\hline $2 \mathrm{pd}$ & - & - & - & - & + & - \\
\hline $1 \mathrm{pb}$ & + & + & - & + & + & + \\
\hline $6 \mathrm{pf}$ & + & + & - & + & - & + \\
\hline $3 \mathrm{pa}$ & + & + & - & + & - & + \\
\hline $6 \mathrm{pe}$ & + & - & - & + & + & + \\
\hline
\end{tabular}

\section{Identificación Molecular}

Mediante la secuenciación del gen que codifica al ARN ribosomal 16S, se identificó las cepas seleccionadas, confirmándose que la mayoría son del género Bacillus (Tabla 8). La mejor cepa 33pa, corresponde a la especie Bacillus pumilus.

Tabla 8. Identificación de las cepas seleccionadas.

\begin{tabular}{cl}
\hline Cepa & \multicolumn{1}{c}{ Identidad } \\
\hline $33 \mathrm{pa}$ & Bacillus pumilus \\
\hline IVpa & Bacillus sp. \\
\hline IIpa & Staphylococcus epidermidis \\
\hline IXpb & Bacillus sp. \\
\hline $2 \mathrm{pf}$ & Bacillus firmus \\
\hline $31 \mathrm{pc}$ & Bacillus pumilus \\
\hline $1 \mathrm{pb}$ & Bacillus subtilis \\
\hline $3 \mathrm{pa}$ & Bacillus sp. \\
\hline $2 \mathrm{pd}$ & Stenotrophomonas maltophilia \\
\hline $6 \mathrm{pe}$ & Stenotrophomonas maltophilia \\
\hline $6 \mathrm{pf}$ & Paenibacillus sp.
\end{tabular}

Evaluación de medios de cultivo para la multiplicación masiva de la mejor cepa seleccionada

Realizado el conteo de bacterias al microscopio, después del crecimiento en los caldos de papa, camote, trigo, cebada, haba y soya, se encontró mediante el análisis de varianza, diferencias altamente significativas entre estos caldos $(\mathrm{p}=0,01)$. El mejor medio de cultivo para la multiplicación masiva de la mejor cepa, fue la papa, presentando la concentración bacteriana más alta (Figura 6).
El caldo de camote reportó la segunda concentración bacteriana más alta, lo que indica, que los caldos con tubérculos y/o raíces, particularmente la papa, favorecen más a la multiplicación de la bacteria, a comparación de los cereales y las leguminosas, lo cual se podría explicar a la procedencia de la bacteria, porque esta bacteria fue aislada como endófito del cultivo de papa cv. Polonia del Altiplano Norte. 


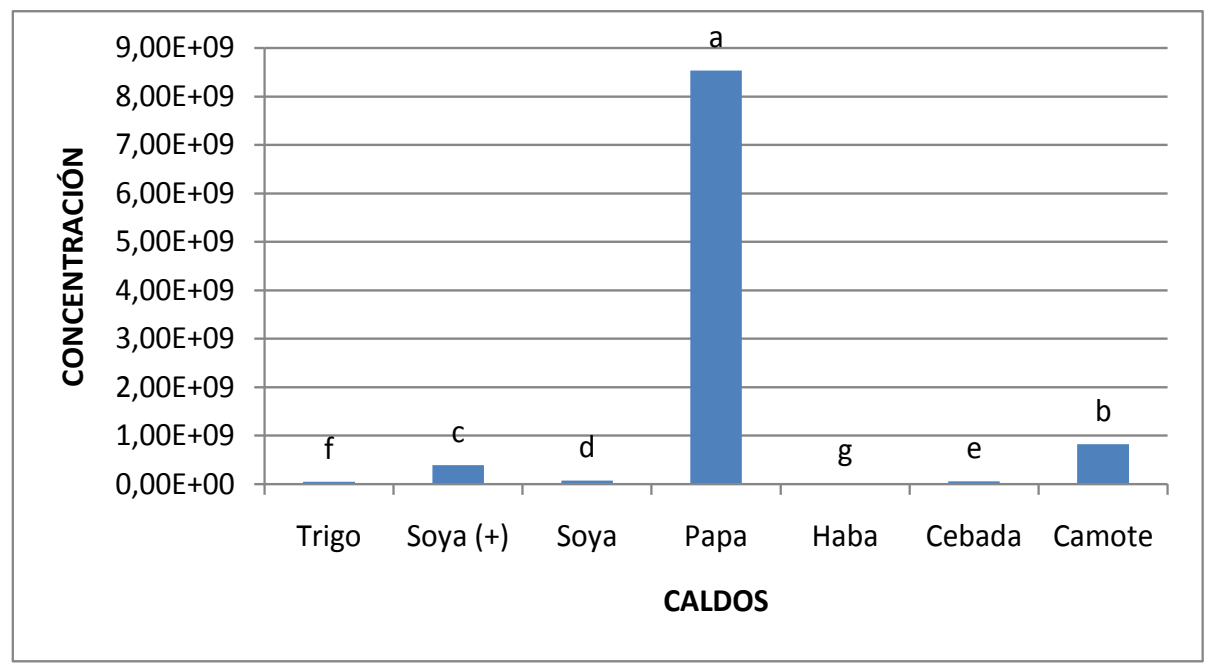

Figura 6. Efecto de diferentes medios de cultivo sobre la multiplicación de Bacillus pumilus.

Por otra parte, se reportó diferente resultado para B. subtilis, por Angulo y Ortuño (2009), cuando probaron diferentes caldos (papa, arroz, soya, papa+soya, arroz+soya y TSB), presentando una mayor multiplicación en el caldo de soya.
En cuanto al $\mathrm{pH}$ inicial de los diferentes caldos, también se encontraron diferencias altamente significativas $(\mathrm{p}=0,01)$, el caldo de soya presentó un $\mathrm{pH}$ más cercano a la neutralidad, en cambio, el pH inicial de la papa fue el más bajo, levemente ácido (Figura 7).

\section{Evaluación del pH}

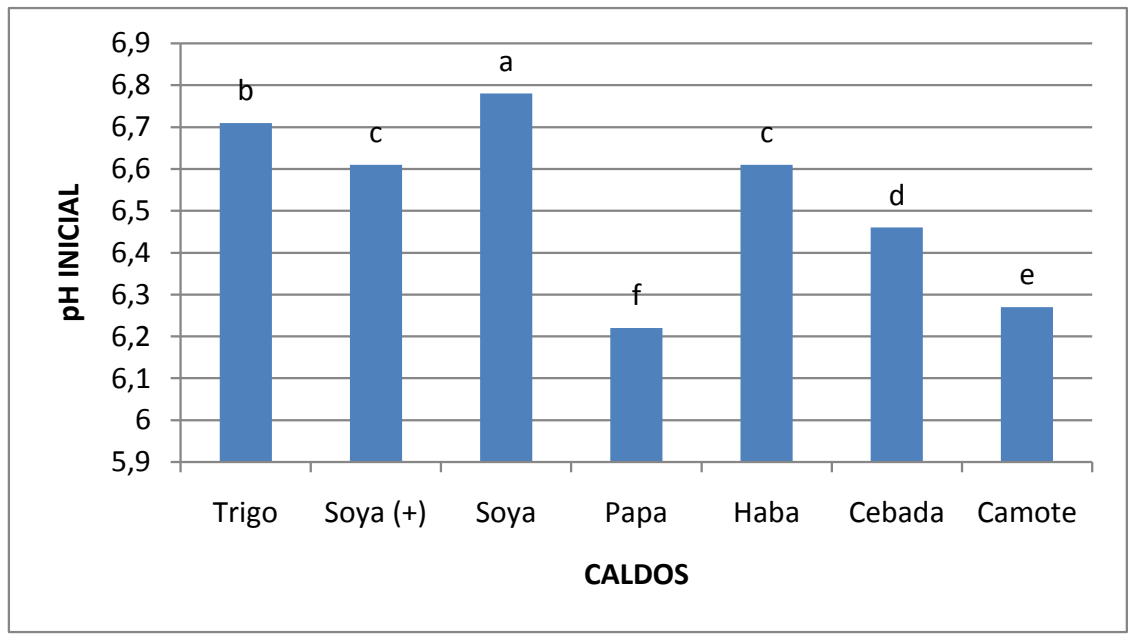

Figura 7. pH inicial de los diferentes caldos. 

El pH final de los caldos, también mostró diferencias altamente significativas $(\mathrm{p}=0,01)$, reportándose al caldo de papa, con el pH final más alto, con tendencias a la alcalinidad, por acción de la multiplicación bacteriana, ya que el caldo testigo (sin inoculación) presentó un $\mathrm{pH}$ final levemente ácido. Es sabido, que los altos niveles de $\mathrm{pH}$ pueden ser importantes en la sobrevivencia, multiplicación y propagación bacteriana (Nautiyal 1999), sin embargo, la composición del caldo de papa, puede ser también un factor determinante en la multiplicación de esta bacteria.

En cambio, la acción bacteriana en el caldo de camote disminuyó el pH, llegando a un estado ácido de $\mathrm{pH}=5,8$ a $\mathrm{pH}=5$, siendo lo opuesto para el caldo de papa (Figura 8). Los caldos de trigo, soya, haba, cebada y sus testigos, presentaron el $\mathrm{pH}$ final cercano a la neutralidad, y sin cambios considerables respecto a su $\mathrm{pH}$ inicial.

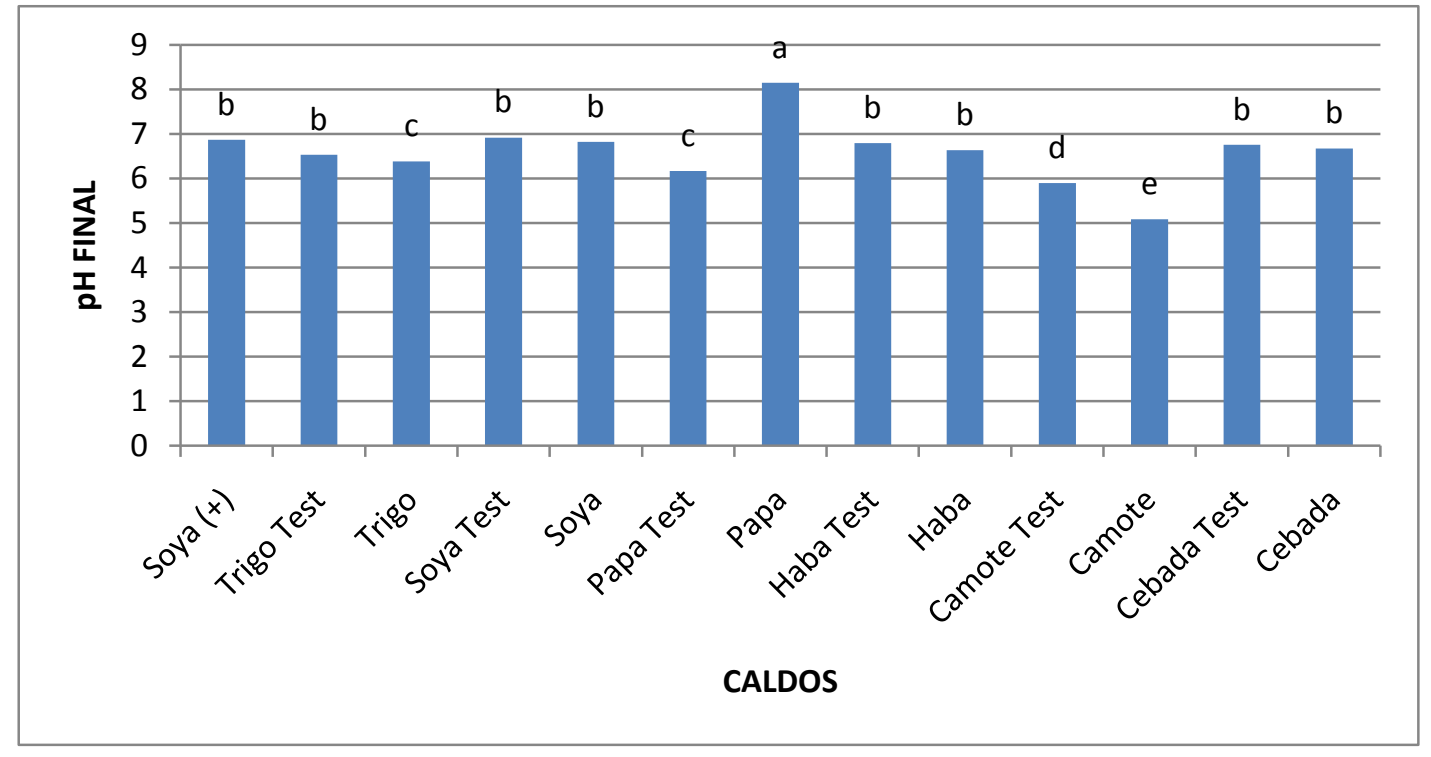

Figura 8. pH final de los diferentes caldos.

El cambio de $\mathrm{pH}$ causada por B. pumilus en los diferentes caldos muestra que la bacteria se comporta de forma diferenciada según el medio de cultivo.

Evaluación de medios de cultivo con diferentes fuentes de energía para la multiplicación masiva
Para mejorar el medio de cultivo seleccionado en el acápite anterior, se realizó pruebas con cuatro diferentes fuentes de azúcares: azúcar blanca, azúcar morena, chancaca y glucosa, donde se encontró diferencias significativas $(\mathrm{p}=0,05)$, siendo la chancaca y el azúcar morena, las que estimularon una mayor multiplicación de B. pumilus (Figura 9). 


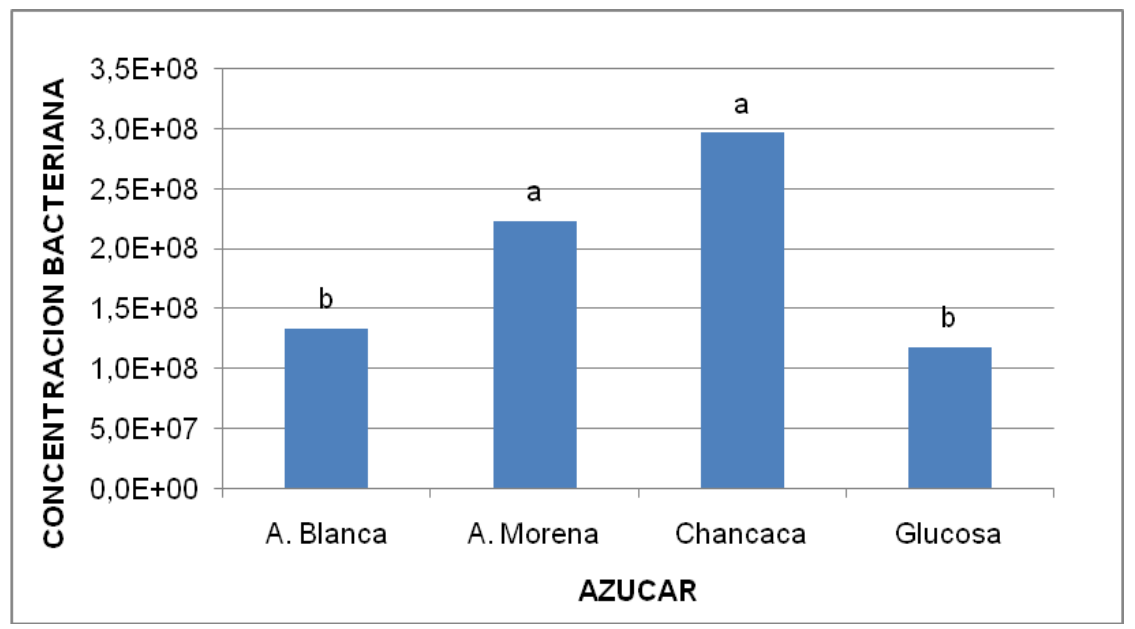

Figura 9. Efecto de diferentes fuentes de azúcar sobre la multiplicación de Bacillus pumilus.

Tanto la chancaca como azúcar morena presentan mayores cantidades de minerales como: fosforo, calcio, magnesio, potasio y hierro, a diferencia de azúcar blanca y glucosa, que presentan estos minerales en cantidades bajas o nulas

(http://www.ccbolgroup.com/chancaca.ht $\underline{\mathrm{ml}}$ ), por lo que la multiplicación de $B$. pumilus, podría estar potenciada por estas propiedades, sin embargo se requiere mas estudios para confirmarlo.

\section{Evaluación del pH inicial}

El pH inicial o el $\mathrm{pH}$ antes de la inoculación de los caldos de papa combinado con los diferentes fuentes de energía, fueron evaluados, donde se presentó diferencias altamente significativas $(\mathrm{p}=0,01)$, siendo el caldo con chancaca el que tuvo el $\mathrm{pH}$ mas bajo $(\mathrm{pH}=5,9)$, y el resto de los tratamientos presentaron un $\mathrm{pH}$ cercano a la neutralidad (Figura 10).

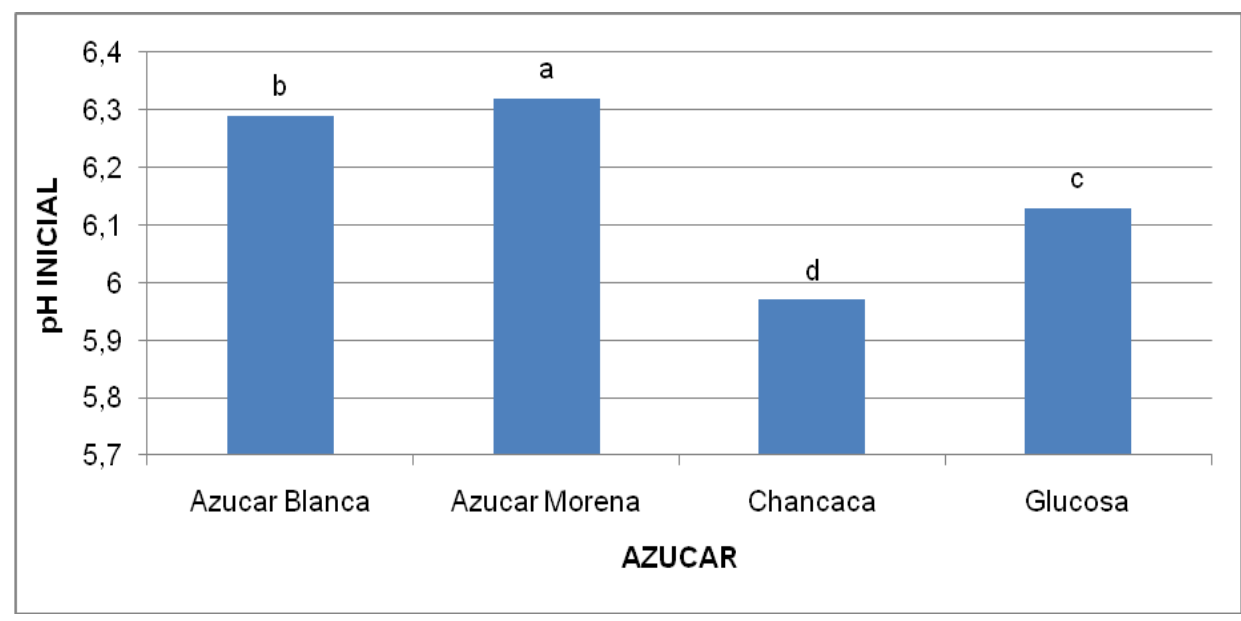

Figura 10. Efecto de azúcares sobre el pH inicial en los medios de cultivo. 


\section{Evaluación del pH final}

También se encontraron diferencias altamente significativas $(p=0,01)$, en el $\mathrm{pH}$ final. Los caldos testigos, es decir, los que no fueron inoculados con la bacteria, presentaron un $\mathrm{pH}$ cercano a la neutralidad $\quad(\mathrm{pH}=6), \quad$ y los caldos inoculados presentaron valores por debajo de $\mathrm{pH}=5,2$, siendo la glucosa el caldo con el $\mathrm{pH}$ más bajo $(\mathrm{pH}=4,8)$, por la acción de la bacteria (Figura 11). Quedando evidente que $B$. pumillus en caldo de papa combinado con los azúcares evaluados, acidifica el medio, pudiendo existir un efecto similar en la rizósfera de la planta. Similar efecto fue reportado por Dulmage, et al. (1990), con Bacillus thuringiensis, que indica que la disminución del $\mathrm{pH}$ en los caldos inoculados, se debe a la producción de ácidos orgánicos, por la oxidación de los carbohidratos.

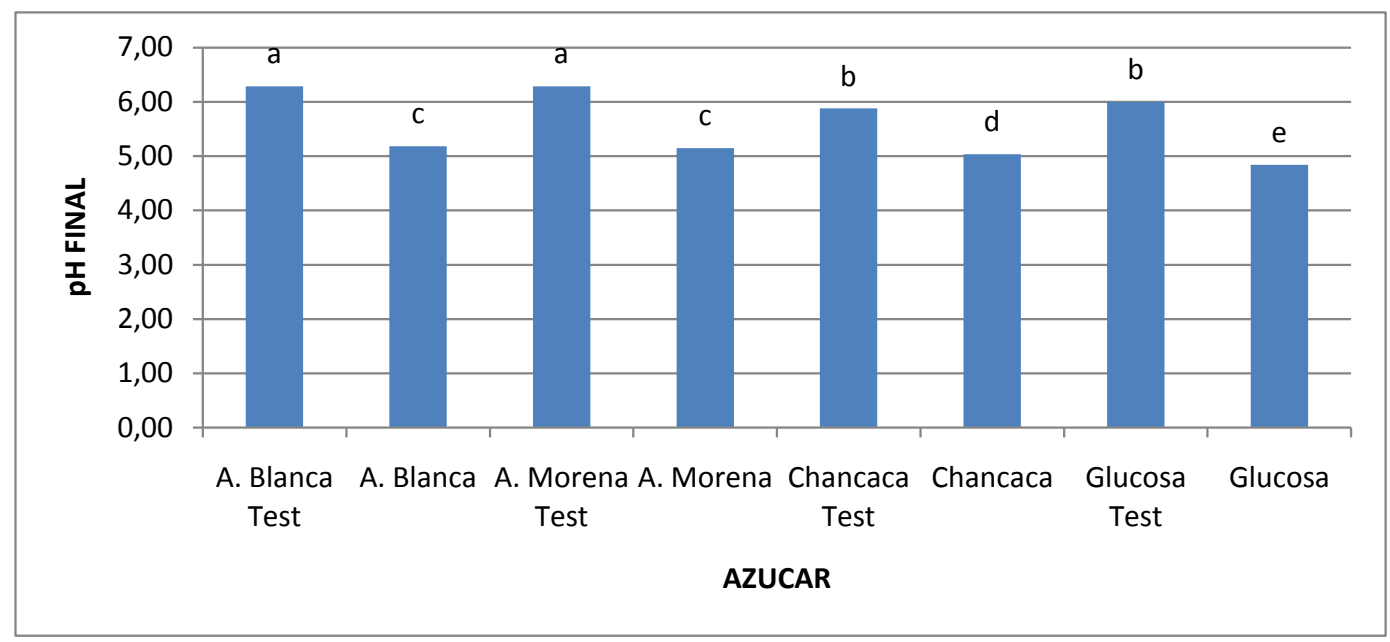

Figura 11. Efecto de azúcares sobre el pH final en los medios de cultivo.

Comparando con los resultados del $\mathrm{pH}$ final de los diferentes caldos (Figura 11), se observó un efecto inverso, el caldo inoculado presento un $\mathrm{pH}$ alcalino $(\mathrm{pH}=8,2)$ respecto a su testigo que presento un $\mathrm{pH}$ levemente ácido $(\mathrm{pH}=6,2)$. Por lo que el caldo de papa con adición de azúcares, se acidula por acción de B. pumilus.

\section{Grados Brix}

En cuanto a la evaluación de los grados Brix en los diferentes caldos, no se encontraron diferencias significativas, $B$. pumilus consume de igual forma los diferentes azúcares. 


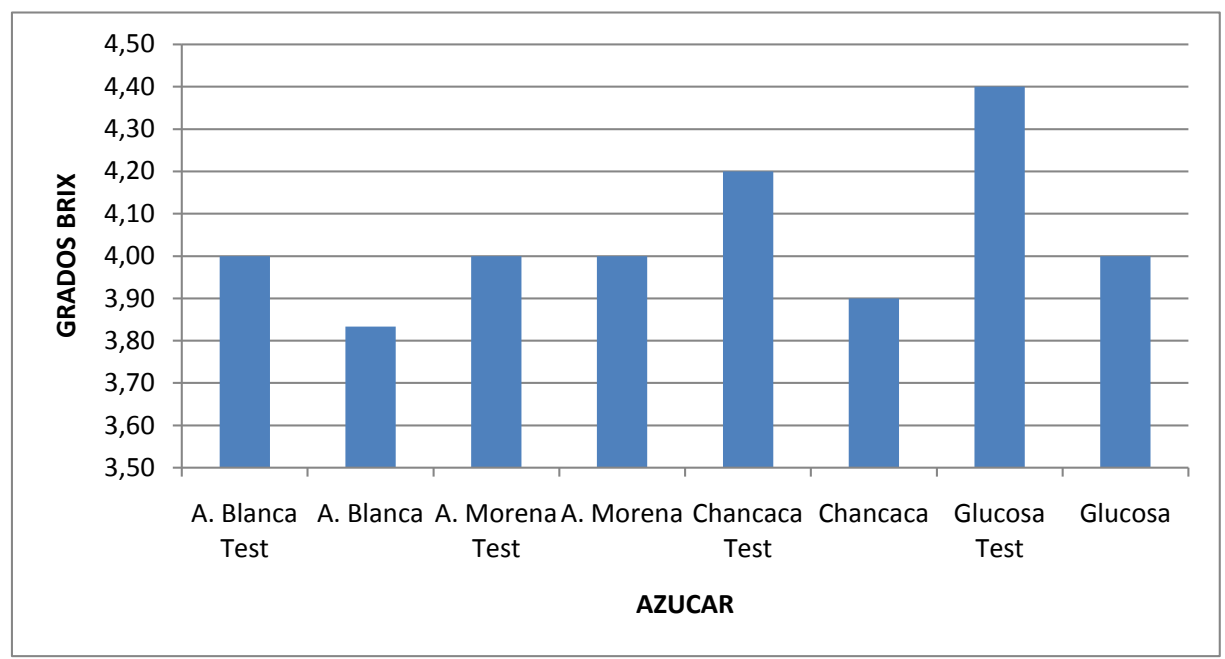

Figura 11. Efecto de las cepas bacterianas sobre los Grados Brix.

Sin embargo, los caldos testigo, presentan promedios más altos, que los caldos inoculados (Figura 11), lo cual se puede explicar al consumo del azúcar por parte de la bacteria, como fuente de energía, propia de la desnitrificación heterótrofa (http://es.wikipedia.org/wiki/Desnitrificac i\%C3\%B3n).
Evaluación de medios inertes para la formulación del biofertilizante

Realizada la formulación en pellet y en polvo, con los caldos enriquecidos con azúcares, se realizó la evaluación de viabilidad, donde se encontraron diferencias altamente significativas $(\mathrm{p}=0,01)$, tanto por el formulado, el tipo de azúcar, y la interacción de ambos.

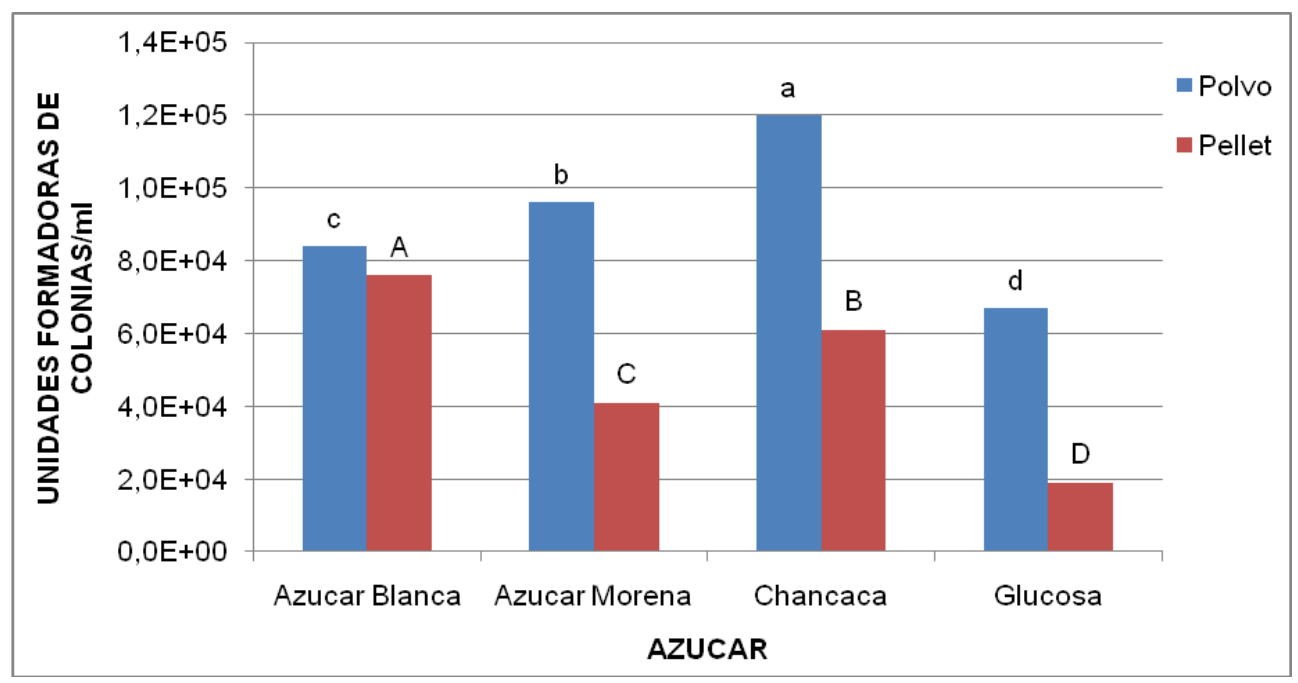

Figura 12. Viabilidad en los formulados con los diferentes azúcares. 
Existe una mayor viabilidad en la formulación en polvo, ya que se encontraron mayor número de unidades formadoras de colonias/ml. Dentro de cada formulación, en el formulado pellet hay una mayor viabilidad con azúcar blanca; asimismo, en el formulado en polvo existe una mayor viabilidad con chancaca (Figura 12).

Estas diferencias en la viabilidad entre el tipo de formulado, se puede explicar a la cantidad de insumos inertes utilizados, es decir, en polvo se utilizó menor cantidad de insumos inertes en relación a la cantidad utilizada en pellet, para la misma cantidad de caldo bacteriano.

Por otra parte, al comparar la población bacteriana en el caldo con las formulaciones sólidas, disminuyen, lo que se podría explicar al método de conteo de la concentración bacteriana, ya que el conteo en los caldos fue realizado en cámara de Neubauer, donde se realiza el conteo de todas las bacterias observadas, en cambio el conteo en los formulados, se realiza a través del conteo de unidades formadoras de colonias en medio de cultivo, es decir solo las bacterias viables; como también se puede explicar a la dilución del caldo con los medios inertes. Similar resultado fue reportado por el Laboratorio de Microbiología, PROINPA (2010), donde $B$. pumilus presentó una concentración de $2,5 \times 10^{8}$ en medio TSB, y el mismo formulado en polvo presentó una concentración de $6,1 \times 10^{5}$. Esto muestra que se debe explorar medios de cultivo más eficientes y medios inertes de bajo volumen para optimizar la población bacteriana después de la formulación.

Se registró también, el tiempo de secado: $2 \mathrm{~kg}$ tardó en secar un día, en ambos formulados; son solubles en agua, y presentan una consistencia en seco, de granulado y polvo.

Según Boland \& Kuykendall (1998), el formulado en polvo, presenta una característica importante, que es el tamaño de la partícula del principio activo, pues cuanto mas pequeño, mejor es su distribución en la superficie del material que va a proteger, por lo que va a conseguir una mayor eficacia. $\mathrm{Y}$ por ser una suspensión al ser mezclado con agua (De Piedrahita et al. 1984), puede utilizarse para su aplicación, una mochila, $\mathrm{u}$ otro equipo, para grandes extensiones de superficie.

El formulado en pellet, según Bravo et al. (2004), presenta como ventaja, que mejora la cohesividad y comprensibilidad del polvo, debido a que el aglutinante cubre las partículas individuales, haciendo que se adhieran unas a otras formando gránulos, mejorando la fluidez, permitiendo la uniformidad del contenido para formulaciones con bajo contenido de ingrediente activo. Por lo que su aplicación es directa al suelo, para extensiones limitadas, pero puede ser mejorado si se dispone de un equipo adecuado para distribuir en grandes extensiones.

En general, las mejores cepas bacterianas seleccionadas a través del ensayo en vivero, fueron: 33pa, IVpa, IIpa, IXpb y $2 \mathrm{pf}$, por que presentaron los valores más altos en las variables de rendimiento, en los dos cultivares de papa evaluadas. Sin embargo, la cepa 33pa, destaca por presentar los promedios más altos en las variables de rendimiento. Esta cepa corresponde a la especie Bacillus pumilus, y se caracteriza por ser solubilizadora de Fósforo y fijadora de Nitrógeno. 

Para la formulación, el mejor medio de cultivo para la multiplicación masiva de la mejor cepa seleccionada, fue el caldo de papa. Así mismo, la adición de chancaca y azúcar morena, optimizaron el caldo de papa, para la multiplicación masiva de esta cepa y la formulación en polvo, presentó mayor viabilidad.

\section{Conflictos de intereses}

Los autores han cumplido las normas de publicación y no generan conflicto de interés en la presente investigación.

\section{Agradecimientos}

Los autores agradecen a la Fundación PROINPA por el apoyo y las facilidades brindadas para la ejecución de esta investigación. Asimismo, al Programa FONTAGRO-BID por el financiamiento proporcionado y su confianza.

\section{Referencias citadas}

Angulo, V.; Ortuño, N. (2009). Optimización de un medio de cultivo Artesanal para la producción de Bacillus subtilis. Informe Anual PROINPA 2009. Proyecto Fontagro - Bioinsumos. p irr.

Bacilio-Jiménez, M.; Aguilar-Flores, S.; Ventura-Zapata, E.; Pérez-Campos, B. E.; Zenteno, E. (2003). Chemical characterization of root exudates from rice (Oryza sativa) and their effects on the chemotactic response of endophytic bacteria. Plant Soil 249: 271-277.

Bacchus, S. 2008. Biopesticide Registration Action Document for Bacillus firmus I-1582. Environmental Protection Agency. United States. 5p.

Benizri E.; Baudoin E. y Guckert A. (2001). Root colonization by inoculated plant growth-promoting rhizobacteria. Biocont. Sci. Technol. 11: 557-574.

Bravo, A.; Buitrago, G.; Cerón, J.; Martinez, J.; Juárez, V. y Uribe, D.
(2004). Bacillus thuringiensis en el control biológico. Universidad Nacional de Colombia. Ed. Buena semilla. Bogotá. 275-290p.

Burbano, H. (1989). El suelo: Una Visión sobre sus componentes Bioorgánicos. Serie de Investigaciones $\mathrm{N}^{\circ} 1$. Universidad de Nariño. Colombia. 337$356 \mathrm{p}$.

Castillo, J. A. (2010). Identificación de cepas bacterianas. Informe anual PROINPA 2010. p irr.

Castro, S. y Roa, C. (2006). Bacterias endófitas de Cordia alliodora Oken y Tabebuia rosea Bertonld D.C. Potencial como promotoras de crecimiento vegetal en la propagación de su hospedero. Pontificia Universidad Javeriana. Bogotá D.C. Colombia. 10-15p.

Chang, R.; Chou, S. y Shaw, J. (2001). Synthesis of Fatty Acid Esters by Recombinant Staphylococcus epidermidis Lipases in Aqueous Environment. Journal of Agricultural and Food Chemistry. Volume 49. 2619-2622p.

CIP. (2008). Protocolos de trabajo con bacterias PGPR. Lima Perú. 47-50p.

Claus, D., y Berkeley, R.C.W. (1986). Genus Bacillus Cohn 1872, pp. 11051139. In P.H.A. Sneath, et al. (eds.), Bergey's Manual of Systematic Bacteriology, Vol. 2. Williams and Wilkins Co., Baltimore, MD.

Cochran, W. y Cox, G. (1965). Diseños Experimentales. Agencia para el desarrollo Internacional (A.I.D.). Mejico DF. 437-481p.

Dobbelaere, S.; Vanderleyden. J. y Okon, Y. (2003). Plant Growth Promoting Effects of Diazotrophs in the Rhizosphere. Crit. Rev. Plant Sci. 22: 107-143p. 
Dulmage, H.T.; Correa, J.A. y GallegosMorales, G. (1990). Potential for improved formulation of Bacillus thuringiensis israelensis through standarization and fermentation development. In: Bacterial control of mosquitoes \& black flies. Edit. Rutgers University. 110-131p.

Garrett, DO.; Jochimsen E.; Murfitt, K.; Hill, B, McAllister S. y Nelson, P.; Spera, R.V.; Sall, R.K.; Tenover, F.C.; Johnston, J.; Zimmer, B. y Jarvis, W.R. (1999). The emergence of decreased susceptibility to vancomycin in Staphylococcus epidermidis. Infect Control Hosp Epidemiol. 20:167-70p.

Juliet, L. y Fernández, A. (2006). Staphylococcus epidermidis. Rev Chil Infec. Santiago, Chile. 23 (3): 247-248p.

Hans, W. y Held, R. (1997). Plant Biochemestry and Molecular Biology. Oxford. University. 395-413p.

Instituto Nacional de Estadística. (2005). Atlas Estadístico de Municipios 2005. La Paz, Bolivia. 697p.

Kapulnik Y. (2002). Plant Growth Promoting by Rhizosphera Bacteria. Plant Roots. The Hidden Half. Ed Marcel Dekker. Nueva York. Estados Unidos de América. 869-887p.

Lee E.Y.; Jun, Y.S.; Cho, K.S. y Ryu, H.W. (2002). Degradation characteristics of toluene, benzene, ethylbenzene, and xylene by Stenotrophomonas maltophilia T3-c. J Air Waste Manag Assoc. National Subsurface Environmental Research Laboratory, Ewha Womans University, Seoul, Korea. 52(4). 400-6p.

López R.; R.; Lado, F. L.; Rodriguez, L.; Gamallo, I.; Lorenzo, V. y RodríguezOtero, Z., L.. (2003). Endocarditis por Stenotrophomonas maltophilia: presentación de un caso y revisión de literatura. An. Med. Interna (Madrid). Vol. 20, no.6, p.42-46. ISSN 0212-7199.

Lugtenberg B.; L., Dekkers y Bloemberg, G. (2001). Molecular determinants of rhizosphere colonization by Pseudomonas. Annu. Rev. Phytopathol. 39: 461-90p.

Metha, S. y S. Nautiyal. (2001). An efficient Method for qualitative screening of phosphate-solubilizing bacteria. Cur. Microbiol. 51-56p.

Nautiyal, S. (1998). An efficient microbiological growth medium for screening phosphate solubilizing microorganisms. FEMS Microbiol. Let.. 265-270p.

Nautiyal, S. (1999). Stress induced phosphate solubilization in bacteria isolated from alkaline soils. FEMS Microbiol. Let. 291-296p.

Penterman, J.N.;Ghosh, S. yTyler, J.R.. 2000. Promotion of root elongation in Canola (Brassica campestris) seedlings by plant growth promoting soil bacteria. American Society of Plant Physiologists. Plant Biology (Abstrac 254).

Peña, H. y Reyes, I. (2007). Aislamiento y Evaluación de bacterias fijadoras de nitrógeno y disolventes de fosfatos en la promoción del crecimiento de la lechuga (Lactuca sativa L.). Interciencia. ISSN 0378-1844.

Pérez, M. y Aquiahuatl, M. (2004). Manual de prácticas de laboratorio de Microbiología General. Universidad Autónoma Metropolitana. México. 18$24 \mathrm{p}$.

Podile, A. R. y Laxmi, V.D.V. (1998). Seed bacterization with Bacillus subtilis AF 1 increases phenylalanine ammonia lyase and reduces the incidence of 
fusarial wilt in pigeonpea. Journal of Phytophatology 146:255-295p.

Servin, P. y Dion P, (2009). Curso práctico-teórico de microbiología agrícola. Importancia de los microorganismos promotores de crecimiento vegetal para los pequeños productores de Bolivia. Fundación PROINPA, Cbba.-Bolivia. 66p.

Sylvia, D. (1999). Principles and applications of soil microbiology. Upper Saddle River. New Jersey: Prentice Hall.

Soberón, J.R.; Quiroga, E.N.; Sampietro A.R. y Vattuore, M.A.. (2005). Auxinas. Argentina. Hipertextos del Área de Biología.

Sturz, A. y Nowak, J. (2000). Endophytic communities of rizobacteria and strategies required to create yield enhancing associations with crops. Appl. Soil Ecol. 15: 183-190.

Surette, M. y Sturtz, A. (2003). Bacterial endophytes in processing carrots (Dacus carota L. var. sativus): their localization, population density, biodiversity and their effects on plant growth. Plant Soil 253: 381-390p.
Tenuta, M. (2004). Plant growth promoting rhizobacteria: prospects for increasing nutrient acquisition and disease control. Departament of soil science. University of Manitoba. 76-82p.

US Environmental Protection Agency. (2004). Biopesticides registration action document Bacillus pumilus strain QST 2808 (PC Code 006485). Office of Pesticide Programs. 5,20p.

Vega, Y. (2007). Evaluación y selección de auxiliares de formulación para la fotoestabilización de la levadura biocontroladora Pichia onychis frente a la radiación ultravioleta. Pontificia Universidad Javeriana. Bogota D.C: 23p.

Waisel, Y.; A. Eshel y U. Kafkafi. (2002). Plant Roots. The Hidden Half. 3rd Edition. 1120p.

Wall L. (2001). Consequences of an overview on PGPR work in Argentina: the Field should be wider. Programa de investigación en interacciones biológicas, Universidad Nacional de Quilmes. Argentina. 